\title{
A NOTE ON ARCTIC OCEANOGRAPHY AND THE LOMONOSOV RANGE
}

\author{
W. G. Metcalf*
}

I

$\mathrm{N}$ THE article by Clifford J. Webster on "The Soviet expedition to the Central Arctic, 1954", published in this number of Arctic, the Russian discovery of the Lomonosov Range and their efforts at mapping and studying the implications of the range have been described.

It may be pointed out that the existence of this submarine range has been inferred and, indeed, actually observed in part by American scientists in the course of studies in the Arctic Basin since 1951. It is interesting that scientists of the two countries working, apparently, from entirely different approaches arrived at identical conclusions concerning this underwater feature.

During ice landings with aircraft north of Alaska in April 1951, Crary et al. (1952a) found the ocean basin in the Beaufort Sea to have a depth of 3,838 metres at $74^{\circ} 45 \mathrm{~N}$., $150^{\circ} 55 \mathrm{~W}$. Worthington (1953) recorded a depth of $2,950 \mathrm{~m}$. about 300 miles north of this point in March 1952. From the oceanographic data gathered by Worthington, the deep water in the Beaufort Sea was shown to be warmer by $0.35^{\circ} \mathrm{C}$ than that in the ocean north of Siberia and Svalbard as described by Nansen (1902) and Sverdrup and Soule (1933).

Worthington believed that this could be explained in one of two ways: either the deep water entering the Arctic Basin from the Norwegian Sea has warmed up since the earlier observations were made, or "there is a submarine ridge, running roughly from Ellesmere to the New Siberian Islands, which separates the deepest water of the Beaufort Sea from the remainder of the basin". Favouring this latter explanation, Worthington predicted from his oceanographic data that the sill depth of the ridge would not be more than $2,300 \mathrm{~m}$. He was not able to estimate how shallow it might be.

Later in 1952, Crary et al. (1952b) reported that in the drift of the ice island $\mathrm{T} 3$, a sea mount or part of a submarine mountain range was crossed at $88^{\circ} \mathrm{N} ., 161^{\circ} \mathrm{W}$. which rises from an ocean basin between 3,750 and $3,900 \mathrm{~m}$. deep to within $2,900 \mathrm{~m}$. of the surface. Other sharp rises from the ocean floor were noted, but as the depth was measured only approximately twice a week from the island, it was felt that the maximum height of the ridge may nowhere have been observed.

Still more recently, Crary (1954) has constructed a bathymetric chart of that part of the Arctic Basin covered by the drift of T3 during the time geophysical parties were stationed on the island. A certain amount of extrapolation of the bathymetry beyond the limits of the actual drift was made

*Woods Hole Oceanographic Institution. 
possible by the fact that the slope as well as the depth of the bottom was observed. The resulting chart shows a distinct submarine mountain range rising to within $1,400 \mathrm{~m}$. of the surface in at least one place. This range was crossed and recrossed numerous times by the drifting ice island. These crossings took place between $871^{\circ}{ }^{\circ}$ and $881 / 2^{\circ} \mathrm{N}$. and $75^{\circ}$ and $180^{\circ} \mathrm{W}$, so that the extension of the range towards Ellesmere Island at one end and the Novosibirskiye Ostrova (New Siberian Islands) at the other is, on the basis of these data, still mostly conjectural. Also, the true peak and sill depth of the ridge, even along the section of the ridge that has been shown positively to exist, cannot be accurately demonstrated by present data.

The Russians views on the surface circulation pattern in the Arctic Basin are also of interest. That a clockwise movement of the ice is present in the Beaufort Sea, has been mentioned by Stefansson and others who made early observations north of Alaska. Farther north, Worthington's oceanographic data disclose a well defined geostrophic current flowing along a clockwise path bounded on the east by the Canadian Arctic Archipelago. The submarine mountain range apparently forms another boundary to this circulation. The frequent crossing of this range by the drifting ice island could be due to local winds moving the ice back and forth as it follows the main circulation pattern.

\section{References}

Crary, A. P., R. D. Cotell, and Jack Oliver. 1952a. "Geophysical studies in the Beaufort Sea, 1951". Trans. Amer. Geophys: Un. Vol. 33, pp. 211-16.

Crary, A. P., R. D. Cotell, and T. F. Sexton. 1952b. "GRD activities on T-3". Progress Reports Nos. 1 and 2, 1 April-15 June 1952 and 15 June-1 October 1952, Geophysical Research Directorate of Air Force Cambridge Research Center, 6 pp. and 8 pp. (also maps).

Crary, A. P. 1954. "Bathymetric chart of the Arctic Ocean along the route of T-3, April 1952 to October 1953". Bull. Geol. Soc. Amer. Vol. 65, No. 7, pp. 709-12.

Koenig, L. S., K. R. Greenaway, Moira Dunbar, and G. Hattersley-Smith. 1952. "Arctic ice islands". Arctic, Vol. 5, pp. 67-103.

Montgomery, Margaret R. 1952. "Further notes on ice islands in the Canadian Arctic". Arctic, Vol. 5, pp. 183-7.

Nansen, Fridtjof. 1902. 'The oceanography of the North Polar Basin'. Christiania: Norwegian Nortb Polar exp. 1893-1896, Scientific Results, Vol. 3, No. 9, 427 pp.

Sverdrup, H. U. and F. M. Soule. 1933. 'Scientific results of the "Nautilus" expedition, 1931'. Papers Phys. Ocean. and Met. Vol. 2, No. 1, 76 pp.

Worthington, L. V. 1953. "Oceanographic results of Project Skijump 1 and Skijump II in the Polar Sea, 1951-1952". Trans. Amer. Geophys. Un. Vol. 34, pp. 543-51. 